\title{
PROFESSOR BOGUMIŁ WITALIS ANDRZEJEWSKI
}

\section{2-1994}

B. W. Andrzejewski, known to all as 'Goosh', was born in Poznan in 1922. His family on his mother's side came from Eastern Poland and had been landowners until the nineteenth century but had lost their land, most probably during the Polish insurrections against the Russian tsars. His maternal grandmother was widowed early in her marriage and made her living as a pianist. His mother died in 1939 after an illness and he owed much of his early upbringing to his grandmother. Goosh remembered her as a wonderful reciter of poetry and stories some of which he could still vividly recall years later. His father's family was from Western Poland, an area which had been part of the German Empire and in which the German language had been promoted to the detriment of the native Polish. This family background he felt had played a role in his strong sympathies with the Somali people who had also suffered under foreign domination.

The Second World War broke out while he was in his penultimate year of high school and he was in Warsaw during the siege of the city, from which he escaped to join the Free Polish Forces abroad and to avoid forced labour. He undertook an arduous illegal journey, through Slovakia, Hungary, Yugoslavia, Greece and Turkey to Palestine, a journey lasting some five to six months full of hardship: hunger, sleeping outdoors in the freezing cold and arrest. $\mathrm{He}$ recounted one particular experience which illustrated the rigours he endured. With a friend, he had escaped from internment in Hungary and, during a snow storm, crossed Lake Balaton, one of Europe's largest lakes. It was a particularly cold spell and the lake had, uncharacteristically, frozen over completely allowing the two men to cross its entire length on foot. This took 12 hours and was done under cover of night against a strong wind, with the help of a luminous compass and provisions given to them by some kindly locals beforehand. While in Hungary Goosh had begun to learn English from a German textbook which promised English in 30 Hours Without a Teacher. Given the great love of language learning which stayed with him all his life one may assume that this study provided a little respite from the hardships of that time.

On his arrival in Palestine Goosh began military training. At the same time he started to learn Arabic and Hebrew, as well as continuing his English learning which now developed apace through his contact with English-speaking soldiers. After training he was posted to an infantry unit in Egypt which was transported to Tobruk, besieged at the time from all sides. He was wounded there and recovered in a hospital in Alexandria. He was then in Gaza for a while at an officer training school, but given what he called a 'lack of talent in that direction' he volunteered for other duties and was posted to a unit escorting German prisoners of war from Port Suez to New York. His linguistic skills, and particularly the fact that he was now able to speak English well, enabled him to act as an interpreter for the Polish forces. The return journey from America to Europe on an American troop ship was spent in sick bay with jaundice and when the ship arrived in the United Kingdom he was sent to a military hospital to recover before being assigned to a Polish artillery unit and then to the Royal Air Force. After a further illness, he took on administrative duties as a clerk and interpreter. It was at this time that he began to pursue his education more systematically by taking a correspondence course from Wolsey Hall in Oxford. He also took an entrance examination and the 
Intermediate examination as an external student of the University of London in English, French, Latin and Logic and Scientific Method.

In October 1944 he was granted leave from military service and began studying English language and literature at Oriel College, Oxford, with a scholarship from the Newman Association. He had already by this stage achieved acclaim as a poet in Polish, something which, along with his academic record favoured his application. He graduated in English in 1947, having specialized on the linguistic side and having studied, among other things, Old Icelandic.

During his time at Oxford he and Sheila (née Weekes) married. They had met in Hucknell near Nottingham during a hospitality weekend for members of the allied forces organized by the local amateur dramatic society. After the end of the war Goosh decided to stay in the United Kingdom and in 1947-48 taught English at a camp for Polish boy refugees liberated from German labour camps. In his spare time he kept up his linguistic and literary interests while looking out for an opportunity to develop them further, whether in postgraduate study or an academic post. In 1948 this hope was realized and his involvement with the Somali language began.

C.R.V. Bell, author of The Somali Language, was at the time Director of Education in the Somaliland Protectorate and had initiated a project to develop a written script for the Somali language. A linguist was therefore sought to work on the structure of the language with Somalis and to develop a script. Goosh was appointed, and in October 1948 he joined the School of Oriental and African Studies as a postgraduate scholar in the Department of Linguistics and Phonetics. He began by studying phonetics and linguistics at an advanced level and he also began to study the Somali language from the material that was available at the time. One of the works most important to him then, and one to which scholars of Somali still refer, was L.E. Armstrong's The Phonetic Structure of Somali. Like Armstrong, Goosh worked with two Somali informants in London, Ali Sheikh Maxamed Jirdey and Anthony Mariano. He also took a course in Arabic, his fascination with this language and its literature having continued since his time in the Middle East.

After this initial stage in London Goosh and Sheila set out, in January 1950 , for the town of Sheikh which was to be the base for the detailed research on the Somali language that now needed to be done. It was there that a most fruitful and indeed famous partnership began between Goosh and Muuse Xaaji Ismacil Galaal, the well known Somali poet and scholar. Muuse Galaal was then a teacher at the school in Sheikh and was released from his duties to join Goosh on the orthography project. They worked on the language under the supervision, by correspondence, of Professor J.R. Firth at SOAS. Their efforts resulted in a report on the phonology of Somali and a recommended system of writing for the language. The system they developed differs little from the present-day orthography. Because of Somali resistance to the roman script, however, their recommendations were never acted on, and it was not until some twenty years later that a script was finally officially adopted.

On returning to London, Goosh became Lecturer in Cushitic Languages at SOAS and continued his collaboration with Muuse Galaal, who had been appointed Research Assistant in Somali for three years. Together they worked not only on the structure of the Somali language but also on the transcription, into their orthography, and translation of folk-tales and poetry, the results of which appeared in a number of articles and books.

Muuse Galaal returned to the Horn of Africa in 1954 and Goosh, while continuing to work on Somali, also began investigating Oromo, a Cushitic 
language related to Somali and widely spoken in Ethiopia, Kenya and in pockets of Somalia. He worked on the language for a year and a half in London with an informant before spending some months in 1957 in Northern Kenya. Although his work on Oromo was not as extensive as that on Somali it is of equal importance in Oromo scholarship, and continues to be referred to.

Like many other African states, Somalia gained its independence in the sixties. One of the most pressing matters for the new government then was the writing of the Somali language and therefore the need to develop a suitable script. In 1966 Goosh was invited by UNESCO to serve with others as a consultant to evaluate various proposals which were submitted to the Somali Language Commission. As before, there were strong feelings on all sides as to which script should be chosen, Roman, Arabic, or a script invented specifically for Somali. Still the government did not make a decision and it was only in 1972 when the military regime of the time accepted the Roman script, and at the same time made Somali the official language of the country, that the question was finally resolved.

As a result, printed books were produced in good numbers, mostly for school and educational use. Written forms of literature also quickly developed and Goosh translated one of the first novels to be written in the Somali language: Aqoondarro wa u nacab jacayl ('Ignorance is the enemy of love'), by Faarax Maxamed Jaamac 'Cawl' (Zed Books, 1982). Goosh's translation of the novel is a fine example of the combination of two skills which he possessed to a high degree: careful, meticulous scholarship and a wonderfully acute translator's sensibility.

Much detailed groundwork was undertaken for the translation. All the places named in the novel were carefully located on maps and all the cultural references were analysed to ensure an accurate rendition of all the nuances and details of the original. Such painstaking thoroughness was representative of his scholarship as a whole. When applied to the grammar of Somali it resulted in formidable pieces of work which demand great perseverance from the reader. Goosh had a rather idiosyncratic way of presenting data, as may be seen in his The Declensions of Somali Nouns (London, 1964) or 'Inflectional characteristics of the so-called 'weak verbs' in Somali' (African Language Studies, 9, 1968), but once this is mastered all the details fall into place.

Goosh's skills as a translator, on the other hand, were undoubtedly nourished by his gifts as a poet of standing in Polish, and although he never composed poetry in English, or indeed in Somali, his many translations of Somali poems into English are a pleasure to read. Goosh often acknowledged that he was helped in this work by his wife, Sheila, and it is fitting that one of his last publications was An Anthology of Somali Poetry translated by them both (Bloomington, Indiana, 1993).

Aside from his work at SOAS Goosh had a longstanding relationship with the Somali Section of the BBC World Service for which he acted as a language supervisor as well as giving talks and taking part in cultural discussion programmes. This, together with all his other work on Somali matters, made him a well known figure to Somalis all over the world who came to know him as 'Macallin Guush', 'Teacher Goosh'. I was forcefully reminded of this when passing through a market area in Djibouti a few years ago. I had paused to speak to a cassette stallholder when the owner of the neighbouring stall joined us to ask if I knew 'Macallin Guush'. When I said that I did, both men asked after him warmly and were full of praise for the man who had devoted so much of his life to the study of their language and culture.

Promotion to the post of Professor of Cushitic Languages and Literatures 
came in 1980, and in 1982 Goosh took early retirement following the budget cuts of that time. As he himself admitted, he felt that he wanted to be free of teaching and administration responsibilities to devote himself entirely to research in the Somali field, especially literature.

This, indeed, he did, but, two years after retirement he was diagnosed as having myasthenia gravis. Although this must have been a grave shock to him and Sheila, with the help of drugs, the illness proved not too great an impediment to his continuing the work which he loved. But further illness, in the form of myeloma was diagnosed in 1991. Despite these serious health problems, Goosh never lost interest in his subject. Over the last few years of his life one of the major projects he undertook was the cataloguing of his research materials and archives which are a rich mine of information for present and future generations of Somalists. The originals are now deposited at Indiana University Library and copies of everything are to be deposited in the SOAS library. This archive is particularly important given that so much has been destroyed in Somalia itself, and there are items in his collection which are not to be found anywhere else in the world. It is to his credit, and characteristic of him, that he produced a detailed catalogue of the material in the archive enabling it to be readily used. He also continued his work on Somali poetics and on the Arabic writings of Somalis.

This great legacy of scholarship apart, so many who knew Goosh personally will have been influenced by him not only through his work but as a personal friend. He was always willing to help anyone who approached him on anything related to his field and he read and responded honestly to anything sent for comment. In conversation he was full of interesting anecdotes which he often used to illustrate a particular point, and he could call on a host of proverbs in many different languages for the same purpose.

A side of Guush which was not accessible to many who knew him through his Somali work was his poetry in Polish. At his memorial service, Jerzy Peterkiewicz, Emeritus Professor of Polish at the School of Slavonic and East European Studies, described Goosh as 'the Maestro of Semantics'. He recalled Goosh's speaking of the 'Semantic Styx' with which he was fascinated and which he tried to cross in his poetry. His creative exploration of words and meanings through poetic imagery at times bore comparison, Professor Peterkiewicz said, with the mystical imagery of poets like Ibn al-Arabi, the great Sufi mystic of Andalusia.

The vivid, creative imagination of the poet and the rigorous, painstaking approach of the scholar came together in Goosh, but were never muddled. His mind and personality were such that he was able to penetrate to the heart of the language and, because of that, his work will not only be referred to in the future, but will continue to inspire scholars of the languages and literatures of the Horn of Africa, those working on Cushitic languages in particular.

MARTIN ORWIN 